\title{
FACTORS AFFECTING AUDIT DELAY IN MANUFACTURING COMPANIES
}

\author{
Wishnu Kameshwara Armand ${ }^{1}$; Bambang Leo Handoko²; Felicia ${ }^{3}$; \\ ${ }^{1,2,3}$ Accounting Department, Faculty of Economics and Communication, Universitas Bina Nusantara \\ Jl. K.H. Syahdan No. 9, Kemanggisan, Jakarta, 021 - 534 5830, Indonesia \\ 1.wishnu.armand@binus.ac.id; ${ }^{2}$ bambang.handoko@binus.edu; ${ }^{3}$ feliciakwee@ rocketmail.com
}

Received: $12^{\text {th }}$ September $2019 /$ Revised: $6^{\text {th }}$ December $2019 /$ Accepted: $7^{\text {th }}$ March 2020

\begin{abstract}
Financial reporting in a timely manner is one of the important factors to maintain the relevance of the information contained in the financial statements of a company. The purpose of this research is to analyze the influence of profitability, solvability, the complexity of operations, audit firm's reputation and company's age on audit delay, partially and simultaneously. This research uses secondary data obtained from goods and consumption industry sector companies listed on the Indonesia Stock Exchange from 2015-2018. This study used a purposive sampling method that produced 28 companies and 112 samples. Sample data were processed using descriptive statistical analysis, classic assumption test and multiple linear regression. The result of the partial significance test shows that the profitability and complexity of operations influence audit delay, while the simultaneous significance test shows that all variables simultaneously influence audit delay.
\end{abstract}

Keywords: Audit Delay, Profitability, Solvability, Complexity, Reputation of Audit Firm, Company's Age.

\section{INTRODUCTION}

Companies that are publicly listed on the Indonesia Stock Exchange require to present financial reports that can be easily accessed so that they can be seen by interested parties with the wider community. The financial statements presented by company management have all the information that is useful for all parties both internal and external to make decisions in the company.

According to the International Accounting Standard Boards (IASB), the main qualitative features or characteristics of financial information are actual relevance and representation, which are strengthened through comparability, verification, timeliness, and understandability. Seeing these qualitative characteristics, timeliness is an important factor in measuring the value of information. The Governmental Accounting Standards Board's Concepts Statement No. 1 shows that financial statements must be available in a timely manner so that decision-makers can make more precise and accurate decisions. The impact of the delay in the issuance of an audit report is not only a delay in the submission of financial statements and a reduction in the relevance of the financial statements but can also impact on the company's Good Corporate Governance because the delay or delay in submission of financial statements can be detrimental to investors and shareholders if they have to make decisions quickly because the information they need is not available when 
it's needed. Further, decision making at the company cannot be done without the timeliness of financial reporting, and this can have fatal consequences for the survival of the company. As of 2018, there were eight companies listed on the Indonesia Stock Exchange (IDX) that were given an extension of the suspension of securities trading as of 2 July 2018 by the stock exchange authorities because they had not completed obligations related to financial reporting and payment of fines for late submission of audit reports, one of which is PT Merck Sharpe Dorme Pharma Indonesia (SCPI) due to companies engaged in the consumer goods industry sector have not fulfilled their obligations related to financial reporting.

A motivation that encourages the authors to conduct this research is inconsistent results from prior studies, for example, profitability has no effect on audit delay as according to Angruningrum and Wirakusuma (2013). But according to Prabasari and Merkusiwati (2017), profitability affects audit delay. According to Saemargani and Mustikawati (2015) and Melati and Sulistyawati (2018), solvency does not affect audit delay, but according to Aryaningsih and Budiartha (2014), solvency affects audit delay. The reputation of KAP is also a variable that can affect audit delay. This statement is supported by research from Ariyani and Budiartha (2014) and Puspitasari and Latrini (2014). But according to Melati and Sulistyawati, (2018) KAP's reputation has no influence on audit delay. Other factors that influence audit delay that will be discussed in this study are the age of the company and also the complexity of the company's operations. According to Widhiasari and Budiartha (2016), the age of the company influences audit delay, but according to Aristika, Trisnawati, and Handayani (2016), the age of the company has no effect on audit delay. Meanwhile, according to Modugu, Eragbhe, and Ikhatua (2012) the complexity of a company's operations affects audit delay. But according to Angruningrum and Wirakusuma (2013) and Puspitasari and Latrini (2014) the complexity of the company's operations does not affect audit delay.

In this study, the independent variables (profitability, solvency, operating complexity,
KAP reputation and company age) are the variables that influence the dependent variable (audit delay). The hypotheses of the research to be conducted by the author can be described as follows:

- Effect of Profitability on Audit Delay Profitability can show the company's ability to generate profits by using assets owned. Companies with high levels of profitability show that the company is running well and has good performance. According to Rahmawati (2015), companies that have a higher level of profitability will spur companies to accelerate the publication of financial statements because by announcing high profits will have a positive impact on the assessment of company performance, while companies that experience losses will delay the publication of financial statements to avoid communicating the bad news. This is in line with research conducted by Saemargani and Mustikawati (2015) and Prabasari \& Merkusiwati (2017) that profitability has a significant effect on audit delay. However Indra and Arisudhana (2012) and Modugu et al. (2012) argues that profitability has no significant effect on audit delay. Thus, the hypotheses that can be formulated are as follows:

$\mathrm{H}_{1}$ : There is a significant influence between profitability to audit delay

- Effect of Solvency on Audit Delay

Solvency can be formulated as a measure of a company's ability to fulfill all its obligations. Basically, a company with a high level of solvency reflects that the company is experiencing financial difficulties. Therefore, it can be formulated that the higher the ratio of debt to total equity in a company, the longer the time span needed to complete an annual financial statement audit. This is supported by research by Angruningrum and Wirakusuma (2013) and also Saemargani and Mustikawati (2015) which shows that solvency has a significant effect on audit delay. But not according to Rahmawati (2015) who argues that there is no significant effect of solvency on audit delay. Thus, the hypotheses that can be formulated are as follows: 
$\mathrm{H}_{2}$ : There is a significant influence between solvency to audit delay

- Effect of Operation Complexity on Audit Delay

The level of complexity of a company's operations can be measured by the number of locations of its operating units (branches) or the number of subsidiaries owned by the company. Referring to these measurements, the complexity of operations will tend to affect the time needed by the auditor to complete his audit work, because the auditor will need more time to audit all transactions of each entity and its subsidiaries. This is in line with research from Darmawan and Widhiyani (2017). But not according to Puspitasari and Latrini (2014) and Angruningrum and Wirakusuma (2013). Thus, the hypotheses that can be formulated are as follows:

$\mathrm{H}_{3}$ : There is a significant influence between the complexity of operations and audit delay

\section{- Effect of KAP Reputation on Audit Delay}

Auditors or public accountants who have a good reputation tend to audit financial statements quickly because they have a high level of experience, knowledge (Prastiwi et al., 2018). A reputable public accounting firm is the largest public accounting firm in the world, or also known as the Big Four Accounting Firms. Big Four reputable KAP are believed to have knowledge and experience that can increase the potential to complete audits of corporate financial statements more quickly. According to Ariyani \& Budiartha (2014) and Puspitasari \& Latrini (2014), KAP reputation has a significant effect on audit delay, but according to Sumartini and Widhiyani (2014) also Saemargani and Mustikawati (2015) KAP reputation has no effect on audit delay. Thus, the hypotheses that can be formulated are as follows:

$\mathrm{H}_{4}$ : There is a significant influence between KAP reputation to audit delay

\section{METHODS}

This type of research used in this study is a quantitative method. Quantitative research methods are used to measure problems by producing numerical data or data that can be converted into statistics. This study is intended to analyze the effect of profitability, solvency, operational complexity, KAP reputation and company age on audit delay in consumer goods industry sector companies listed on the Indonesia Stock Exchange for the period 2015-2018.

The research subjects to be examined are companies in the consumer goods industry sector which were listed on the Indonesia Stock Exchange in the 2015-2018 period. Data collected for this research are secondary data, i.e. financial statements and audit reports of each company. This study aims to examine the effect of independent variables namely profitability, solvency, the complexity of operations, the reputation of the firm and the age of the company to the dependent variable, namely audit delay. The object of this research is the financial statement data of the consumer goods industry sector in the 2015-2018 period, namely profitability, solvency, the complexity of operations, the reputation of the firm and age of the company. The data taken is total assets, net income, total equity, total liabilities, company standing year, auditor services used and the date the audit report was published.

The population taken in this study is companies in the consumer goods industry sector which are listed on the official website of the Indonesia Stock Exchange for the period 20152018. While the sample is a portion of the population studied. The sample selection is done by a purposive sampling technique, where the sample is selected using predetermined sample selection criteria. The criteria referred to are as follows:

1. Consumers of industrial goods companies listed on the Indonesia Stock Exchange for the period 2015-2018.

2. The company publishes financial statements with independent auditors' reports for 4 consecutive years (20152018).

3. The company presents financial statements in Rupiah.

The data analysis method used in this study is the multiple linear regression. After all the classic assumption tests meet the existing requirements, then a multiple linear regression 
test can be performed. In linear regression, the variable y can be called the dependent variable and the $\mathrm{x}$ variable the independent variable. The independent variable is a variable that can predict the dependent variable. Multiple linear regression tests were performed to see whether there was a relationship between the independent variables and the dependent variable. Multiple linear regression is a continuation of simple linear regression because simple linear regression can only help determine the effect of one independent variable on a dependent variable, while multiple linear regression can help to determine the effect of several independent variables on one dependent variable.

The classic assumption test is a statistical requirement that must be met in multiple linear regression based on Ordinary Least Square (OLS). There are at least four classic assumption tests, namely the multicollinearity test, the heteroscedasticity test, the normality test, and the auto-correlation test.

A normality test is done to find out whether the data taken has a normal distribution population or not. The normality test conducted in this study is the Kolmogorov-Smirnov test because this test does not cause differences in perception between one observer and another observer, as in the normality test using graphics. The application in the Kolmogorov-Smirnov test is as follows:

1. If Sig> 0.05 then the data is normally distributed.

2. If Sig <0.05, the data are not normally distributed.

The basis for decision making from the normal probability plot analysis is as follows:

1. If the data spread around the diagonal line and follows the direction of the diagonal line, then it shows a normal distribution pattern, then the regression model meets the normality assumption.

2. If the data spreads far from the diagonal line and does not follow the direction of the diagonal line and does not show a normal distribution pattern, then the regression model does not meet the assumption of normality.
Multicollinearity test aims to test whether the regression model found a correlation between independent variables or not. If there is a high correlation between independent variables, the relationship between independent variables and the dependent variable will be disturbed. The basis for decision making in the Multicollinearity test can be done in two ways namely:

1. If the correlation coefficient between each independent variable is more than 0.10 and less than 10 , then the model can be declared free of Multicollinearity.

2. If the correlation value is more than 10 then it can be stated that there is a very strong correlation between variables so that multicollinearity occurs.

A heteroscedasticity test is performed to determine whether data has the same variance between the data. The expected data are homoscedasticity data and free from heteroscedasticity. To detect the existence of heteroskedasticity can be done by looking at a scatter plot graph between the predictive value of the dependent variable (ZPRED (x-axis) and the residual SRESID (y-axis), if certain patterns are formed such as dots that form regular patterns (wavy), widened, then narrowed) then indicated heteroscedasticity had occurred. If on the contrary, the pattern is irregular and the points spread above and below the number 0 on the $\mathrm{Y}$-axis then there is no heteroscedasticity.

Autocorrelation test is part of the classic assumption test that is used to see the form of interference from different observations, in other words, the purpose of the autocorrelation test is to find out whether in the linear regression model there are strong correlations that are positive or negative. If the results of the calculation found a correlation on the data then it is assumed that there are problems with autocorrelation. To find out the occurrence of autocorrelation, a Durbin Watson test is performed, namely by comparing the d value of the regression results with dl (lower bound) and $\mathrm{du}$ (upper bound) of the Durbin Watson table. The following are the terms of Durbin Watson:

1. DU <DW <4-DU then H0 is accepted, meaning that there is no autocorrelation. 
2. DW $<\mathrm{DL}$ or $\mathrm{DW}>4-\mathrm{DL}$ then $\mathrm{H} 0$ is rejected, meaning autocorrelation occurs.

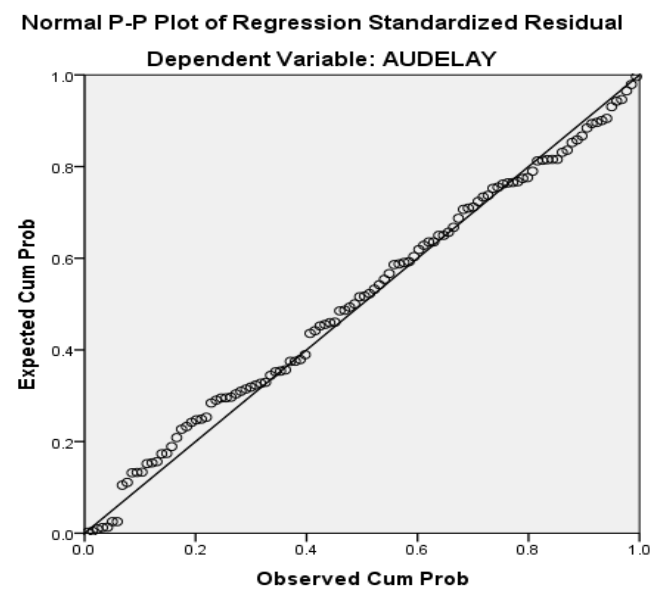

3. $\mathrm{DL}<\mathrm{DW}<\mathrm{DU}$ or $4-\mathrm{DU}<\mathrm{DW}<4-\mathrm{DL}$, meaning that there is no certainty or a definite conclusion.

The F test is a model feasibility test that can be used to estimate the population. A regression model is said to be feasible if the $\mathrm{F}$ of a model meets established criteria. The criterion of the $\mathrm{F}$ test is that if the significance probability value $<0.05$, the hypothesis is accepted. This means the regression model can be used to predict independent variables. If the significance value is $>0.05$, the hypothesis is rejected (Estrini, 2013).

A t-test is used to determine whether the independent variables partially have a significant effect on the dependent variable. If the significant value is less than the degree of confidence of $5 \%$ or 0.05 , it can be concluded that the independent variable partially influences the dependent variable.

The decision-making criteria for this t-test are as follows:

1. H0 is accepted if t-count $>\mathrm{t}$-table and or significance value $<0.05$

2. H0 is rejected if t-count $<\mathrm{t}$-table and or significance value $>0.05$

The coefficient of determination is used to see how far an independent variable determines changes in the value of the dependent variable. The coefficient of determination ranges from zero to one. Greater the value of the coefficient of determination, greater ability of the independent variable in explaining the dependent variable.

Smaller the value of the coefficient of determination; smaller the ability of the independent variable in explaining the dependent variable.

\section{RESULT AND DISCUSSION}

In the normality test, it can be seen that the probability plot image shows that the data distribution follows the direction of the diagonal line which indicates that there is no normality problem, and this is reinforced by the results of the Kolmogorov-Smirnov test showing a significance of 0.200 which indicates that the data distribution is normal.

Figure 1 Normal Probability Plot

Table 1 Kolmogorov-Smirnov Test

\begin{tabular}{llr}
\hline & & $\begin{array}{c}\text { Unstandardized } \\
\text { Residual }\end{array}$ \\
\hline $\mathbf{N}$ & & 112 \\
\hline $\begin{array}{l}\text { Normal } \\
\text { Parameters a,b }\end{array}$ & Mean & .0000000 \\
\cline { 2 - 3 } & Std. & 10.39421752 \\
\hline Most & Deviation & \\
Extreme & Absolute & .056 \\
\cline { 2 - 3 } Differences & Positive & .040 \\
\cline { 2 - 3 } & Negative & -.056 \\
\hline Test Statistic & & .056 \\
\hline Asymp. Sig. (2-tailed) & $.200^{\text {c,d }}$ \\
\hline
\end{tabular}

Furthermore, in the heteroscedasticity test in Figure 2 it can be seen that irregular patterns and points spread above and below the number 0 on the $\mathrm{Y}$-axis can be concluded that there is no heteroscedasticity problem. 
Figure 2 Heteroscedasticity Test

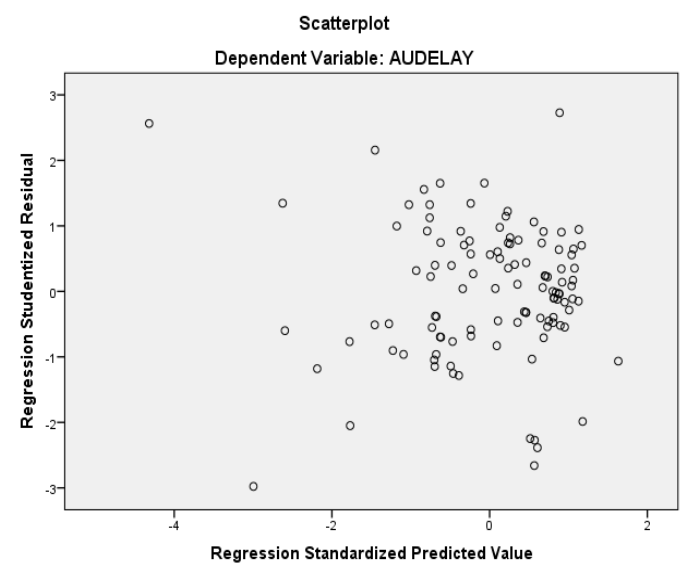

In the autocorrelation test, it can be seen that the Durbin-Watson value obtained is 2.104 and the Durbin-Watson Upper or DU value from the Durbin-Watson table is 1.8060 and the DurbinWatson Lower or DL value is 1.5809. Based on the terms of Durbin-Watson DU <DW <4-DU $(1.8060<2.104<(4-1.8060)$, it can be concluded that there is no autocorrelation problem.

\section{Table 2 Autocorrelation Test with Durbin- Watson}

\begin{tabular}{cc}
\hline $\begin{array}{c}\text { Adjusted R } \\
\text { Square }\end{array}$ & $\begin{array}{c}\text { Durbin- } \\
\text { Watson }\end{array}$ \\
\hline $\mathbf{. 1 3 4}$ & 2.104 \\
\hline
\end{tabular}

F statistical test aims to determine the effect of the independent variables together on the dependent variable. If the significance value indicates a result smaller than 0.05 , simultaneously the independent variable influences the dependent variable. Conversely, if the significance value is greater than 0.05 then all the independent variables simultaneously have no effect on the dependent variable.

\begin{tabular}{|c|c|}
\hline Table & T-Test \\
\hline $\mathbf{F}$ & Sig. \\
\hline 4.422 & $.001^{b}$ \\
\hline
\end{tabular}

The partial significance test or t-test aims to see whether the independent variable partially or fragmentary influences the dependent variable. If the significance value shows a result smaller than 0.05 then the independent variable influences the dependent variable. The t-test results can be seen in Table 4 as follows:

Table 4 T-test

\begin{tabular}{lcc}
\hline \multicolumn{1}{c}{ Model } & \multicolumn{1}{c}{ t } & Sig. \\
\hline (Constant) & 21.309 & .000 \\
\hline PROFIT & -2.064 & .041 \\
\hline SOLVA & -.058 & .954 \\
\hline COMPLEX & 2.393 & .018 \\
\hline KAP & -.109 & .913 \\
\hline UMUR & -.948 & .345 \\
\hline
\end{tabular}

The coefficient of determination test is done to measure how much the ability of the regression model in explaining the dependent variable, namely audit delay. The value of the coefficient of determination is shown in the value of Adjusted R2. As shown in table 5, the coefficient of determination test results shows the adjusted $\mathrm{R}$ square value of 0.134 which means that the independent variable has the ability to explain the dependent variable by $13.4 \%$, while $86.6 \%$ is explained by other variables outside this study.

Table 5 Determination Coefficient Test

\begin{tabular}{|c|c|}
\hline $\begin{array}{c}\text { Adjusted } R \\
\text { Square }\end{array}$ & .134 \\
\hline
\end{tabular}

Profitability in this study was measured by ROA (Return on Assets). In accordance with the hypothesis test that has been conducted in this study, it was found that profitability has a significant negative effect on audit delay. This research found that when companies get more profit, the time needed to process and produce information and financial reporting is reduced. The results of hypothesis testing in this study indicate that profitability has a significant negative effect on audit delay, this is evidenced by the significance value of the profitability variable of 0.041 , which is smaller than 0.05 and the $t$-value of -2.064 which is greater than the $t-$ table, which is 1.983 . 
Companies that have higher profitability have a shorter audit delay because high profitability is good news for companies and investors, so the company will not delay publishing the financial statements. Conversely, companies that experience losses tend to have a longer audit delay.

In this study, solvency is measured from Debt to Equity Ratio which is calculated from the division of Equity from Total Debt. In accordance with the hypothesis test conducted in this study, it was found that solvency did not have a significant effect on audit delay. This is evidenced by the significance value of the solvency variable of 0.954 which is greater than 0.05 and the t-test value of 0.058 which is smaller than the t-table of 1.983 .

A high level of solvency does not always have a negative impact on financial reporting on the company because if the company manages to manage its debt well, efficiently and on target, the company will continue to benefit and there will be no problems with financial difficulties that can slow the delivery of financial statements. In addition, the size of the debt in a company should not affect the audit process because the auditor still must conduct the audit process in a timely manner and follow applicable standards.

The complexity of a company's operations in this study is measured by the presence or absence of a subsidiary in the company. Based on the hypothesis test that has been carried out in this study, the complexity of operations has a significant positive effect on audit delay. This is evidenced by the significance value of the operating complexity variable of 0.018 which is smaller than 0.05 and the t-value of 2.393 which is greater than the t-table value of 1.983 .

The results of this study indicate that companies that have subsidiaries have a longer audit delay than companies that do not have subsidiaries. This can be caused by auditors who need more time to audit the financial statements of each company business unit and ensure that all financial statements are properly presented.

Firms affiliated with Big Four Firms are considered to have more competence and experience than Firms that are not affiliated with Big Four, given the size of the Big Four companies that are large and recognized throughout the world. Based on the hypothesis test that has been carried out in this study, it was found that the reputation of KAP did not have a significant effect on audit delay. This is evidenced by the significance value of the KAP reputation variable that is equal to 0.913 which is greater than 0.05 and also the t-value of the KAP reputation variable is -0.109 which is smaller than the t-table value is 1.983 .

The results of this study indicate that companies that use the services of the Big Four KAP do not guarantee that the audit delay time will decrease, and the initial hypothesis is rejected. Although most of the consumer goods industry companies listed on the Indonesia Stock Exchange in the 2015-2018 period that used the services of the Big Four KAP had a relatively short audit delay period, there were still companies that used the services of the Big Four KAP which had a relatively long audit delay period. On the other hand, KAP Non-Big Four also has a competent and professional workforce so that it can complete the audit process in a timely manner without exceeding the deadline set.

The age of the company is calculated from the year the company was founded until the financial year. Companies that have been operating for a long time are considered to have strong internal controls so that they are able to produce financial information quickly. Based on the hypothesis test that has been conducted in this study, it was found that the age of the company had no effect on audit delay. This is evidenced by the significance value of the company age variable that is 0.345 which is greater than 0.05 and the t-value of the company age variable is -0.948 which is smaller than the $t-$ table value that is 1.983 .

Based on the data that has been taken, many not all companies that are mature have an audit delay period in a short time. The results of this study indicate that an adult company does not determine that the presentation of financial statements can be carried out in a timely manner because it turns out that young companies also try to comply with established regulations by presenting financial statements in a timely manner. 


\section{CONCLUSIONS}

This study aims to look at the relationship between the independent variables namely profitability, solvency, the complexity of operations, the reputation of the firm and age of the company and the dependent variable that is audit delay in the consumer goods industry sector companies listed on the Indonesia Stock Exchange period 2015-2018. Based on the results of hypothesis testing, the conclusions that can be drawn are as follows:

1. The average audit delay in the consumer goods industry sector companies listed on the Indonesia Stock Exchange in the 2015-2018 periods is 75.20 or 75.2 days. This shows that most companies in the consumer goods industry sector listed on the Indonesia Stock Exchange have tried to follow the applicable regulations by publishing financial statements sooner than the specified deadline, which is 90 days after the closing date of the company book.

2. Profitability partially has a significant influence on audit delay. Companies with higher levels of profitability tend to publish financial statements more quickly than companies with lower levels of profitability.

3. Partial solvency does not have a significant effect on audit delay. High or low Debt to Equity ratio in the company does not affect the audit delay period. This is because even though the company has high solvency if it can manage debt well, the company will still be able to benefit and continue to publish financial reports as soon as possible.

4. The complexity of operations partially has a significant effect on audit delay. Companies that have subsidiaries will need more time in submitting financial statements because the audit process will take longer because the auditor must audit each transaction of each entity and subsidiary.
5. Audit firm reputation partially has no significant effect on audit delay. This is because Audit firm affiliated with nonbig four audit firms also has a professional workforce and are still trying to maintain their reputation by conducting audit procedures correctly and on time.

6. The company's age partially has no significant effect on audit delay. This is because companies that are classified as young also try to follow applicable regulations and attempt to publish financial reports as soon as possible to maintain a good reputation and attract the attention of investors.

Based on the test results, conclusions and limitations of this study, the authors have the following suggestions:

1. The next researcher is suggested to increase the scope of the research and or increase the number of companies and samples studied. In addition, the addition of the number of variables is also possible to clarify the factors that influence audit delay. Because in this study only using secondary data, researchers are expected to further research using primary data to find real problems that occur within the company or the auditing process.

2. Companies are expected to pay attention to the level of profitability because this study found that profitability affects audit delay. The company is expected to strive to increase or maintain profitability to avoid the process of preparing financial statements that are too long.

3. This study found that the complexity of operations as measured by the number of subsidiaries owned can affect the audit delay period. Auditors are advised to carry out audit planning such as interim audits, ensuring the number of audit teams is sufficient to carry out audits and communication with clients 
regarding the schedule for conducting field audits

4. Investors \& users of financial statements in investing or investing are advised to pay attention to the company's financial condition, especially profitability and number of subsidiaries, bearing in mind these two things affect the audit delay period which can affect decision making.

\section{REFERENCES}

Angruningrum, S., \& Wirakusuma, M. G. (2013). Pengaruh Profitabilitas, Leverage, Kompleksitas Operasi, Reputasi KAP dan Komite Audit Pada Audit Delay. E-Jurnal Akuntansi Universitas Udayana, 5(2), 251270.

Aristika, M. N., Trisnawati, R., \& Handayani, C. D. (2016). Pengaruh Opini Audit, Ukuran Perusahaan, Umur Perusahaan dan Laba Rugi terhadap Audit Report Lag.Menakar Peran Profesi sebagai Engine of Reform dalam Pembangunan Global Berkelanjutan (559-568). Surakarta: Universitas Muhammadiyah Surakarta..

Ariyani, N. N. T. D., \& Budiartha, I. K. (2014). Pengaruh Proftabilitas, Ukuran Perusahaan, Kompleksitas Operasi Perusahaan, dan Reputasi KAP terhadap Audit Report Lag pada Perusahaan Manufaktur. E-Jurnal Akuntansi Universitas Udayana, 8(2), 217230.

Gani, I., \& Amalia, S. (2015). Alat Analisis Data: Aplikasi Statistik untuk Penelituan Bidang Ekonomi dan Sosial (1st ed.). Yogyakarta: ANDI.

Handayani, T. (2016). Pengaruh Perputaran Modal Kerja, Perputaran Piutang, dan Perputaran Kas Terhadap Profitabilitas Perusahaan (Survei pada Perusahaan Property dan Real Estate yang Terdaftar di Bursa Efek Indonesia Periode 2012-2014). Jurnal Akuntansi Dan Sistem Teknologi Informasi, 12(2), 259-265.

Indra, N. S., \& Arisudhana, D. (2012). FaktorFaktor yang Mempengaruhi Audit Delay Pada Perusahaan Go Public di Indonesia (Studi Empiris pada Perusahaan Property dan Real Estate di Bursa Efek Indonesia periode 2007-2010). Jurnal Akuntansi Dan
Keuangan, Vol.1 No. 2, 165-184.

Melati, L., \& Sulistyawati, A. I. (2018). Audit Delay Pada Perusahaan Pertambangan: Analisis Dan Faktor-Faktor Penentunya. Jurnal Akuntansi Indonesia, 5(1), 37.

Modugu, P. K., Eraghbe, E., \& Ikhatua, O. J. (2012). Determinants of audit delay in Nigerian companies: Empirical evidence. Research Journal of Finance and Accounting, 3(6), 46-54.

Prabasari, I. G. A. A. R., \& Merkusiwati, N. K. L. A. (2017). Pengaruh Profitabilitas, Ukuran Perusahaan, Dan Komite Audit Pada Audit Delay Yang Dimoderasi Oleh Reputasi KAP. E-Jurnal Akuntansi Univeristas Udayana, 20(2), 1704-1733.

Prastiwi, P. I., Astuti, D. S. P., \& Harimurti, F. (2018). Pengaruh Ukuran Perusahaan, Leverages, Sistem Pengendalian Internal, dan Reputasi Auditor Terhadap Audit Delay dengan Audit Tenure Sebagai Variabel Moderasi. Jurnal Akuntansi Dan Sistem Teknologi Informasi, Vol. $14 \mathrm{No}$, 89-99.

Puspitasari, K. D., \& Latrini, M. Y. (2014). Pengaruh Ukuran Perusahaan, Anak Perusahaan, Leverage dan Ukuran KAP Terhadap Audit Delay. E-Jurnal Akuntansi Universitas Udayana, 8(2), 283-299.

Rahmawati, S. E. (2015). Pengaruh faktor internal dan eksternal perusahaan terhadap audit delay. Jurnal Ilmu \& Riset Akuntansi, $4(7), 1-15$.

Saemargani, F. I., \& Mustikawati, I. (2015). Pengaruh Ukuran Perusahaan, Profitabilitas, Solvabilitas Dan Opini Auditor Terhadap Audit Delay. JURNAL NOMINAL, 4(2).

Sumartini, N. K. A., \& Widhiyani, N. L. (2014). Pengaruh Opini Audit , Solvabilitas , Ukuran KAP dan Laba Rugi pada Audit Report Lag. Pengaruh Opini Audit, Solvabilitas, Ukuran Kap Dan Laba Rugi Pada Audit Report Lag, 9(1), 392-409.

Widhiasari, N. M. S., \& Budiartha, I. K. (2016). Pengaruh Umur Perusahaan, Ukuran Perusahaan, Reputasi Auditor, dan Pergantian Auditor Terhadap Audit Report Lag. E-Jurnal Akuntansi Universitas Udayana, 15(2), 200-227. 
